\title{
EFICIÊNCIA DA JUSTIÇA CRIMINAL: AVALIAÇÃO DINÂMICA EM UM ESTUDO DE CASO ${ }^{1}$
}

Andrei Gomes Simonassi²

Denise Xavier Araújo de Oliveira ${ }^{3}$

Ronaldo de Albuquerque e Arraes ${ }^{4}$

0 artigo tem como foco central uma das principais causas que contribuem para a manutenção ou incremento de crimes de homicídios dolosos consumados: a impunidade. Este fato motivou a condução de uma análise dinâmica ao longo dos processos judiciais. Foram utilizados dados para os casos de homicídios dolosos ocorridos em 2014 na cidade de Fortaleza, e a sua apuração temporal foi acompanhada de forma a viabilizar a verificação da representatividade da parcela desses crimes aos quais não houve imposição da pena prevista em lei. Com aplicação de técnicas de análise de sobrevivência às fases do processo de investigação, sobressai-se o fato de que o maior entrave à apuração de crimes emerge na fase de investigação policial, além da comprovação de apenas $1 \%$ de crimes ter sido julgado de um total de 1.896 cometidos. Somados os demais resultados do estudo, conclui-se que há necessidade premente de elaboração de novas metodologias de trabalho, no sentido de efetivar, dentro dos limites legais, a captura do autor do crime ainda em situação de flagrante delito.

Palavras-chave: fluxo da Justiça criminal; homicídio doloso; análise de sobrevivência.

\section{EFFICIENCY OF CRIMINAL JUSTICE: DYNAMIC ASSESSMENT IN A CASE STUDY}

The paper deals with one of the main causes that contribute to the maintenance or increase of crime of voluntary murder: impunity. The only disclosed data for the city of Fortaleza in 2014 revealed that many registered cases had no imposition of the penalty by law. This fact brought about motivation for this paper. By applying survival analysis techniques during the investigation process, it is concluded that the greatest obstacle along crime investigation emerges in the initial phase of police investigation itself. It is also revealed that out of 1.896 committed crimes, less than $1 \%$ was trialed. These and the other findings call for other enforcement mechanisms in order to provide effective methods, within legal limits, for the capture of the crime author still in flagrant delicto situation.

Keywords: flow of criminal justice; willful homicide; survival analysis.

1. DOI: http://dx.doi.org/10.38116/ppp56art7

2. Pesquisador do Conselho Nacional de Desenvolvimento Científico e Tecnológico (CNPq).E-mail: <agsimonassi@ufc.br>.

3. Doutora em Economia pelo Programa de Pós-graduação em Economia da Universidade Federal do Ceará (Caen-UFC).

E-mail:<denisexaraujo@gmail.com>.

4. Pesquisador do CNPq. E-mail: <ronald@ufc.br>. 


\section{EFICIENCIA DE LA JUSTICIA PENAL: EVALUACIÓN DINÁMICA EN UN ESTUDIO DE CASO}

El artículo tiene como foco central una de las principales causas que contribuyen al mantenimiento o incremento de crímenes de homicidios dolosos consumados: la impunidad. Este hecho motivó la conducción de un análisis dinámico a lo largo de los procesos judiciales. Se utilizaron datos para los casos de homicidios dolosos ocurridos en 2014 en la ciudad de Fortaleza, y su recuento temporal fue acompañado de forma a viabilizar la verificación de la representatividad de la parcela de estos crímenes a los cuales no hubo imposición de la pena prevista en ley. Con la aplicación de técnicas de análisis de supervivencia a las fases del proceso de investigación, destaca el hecho de que el mayor obstáculo al escrutado de crímenes emerge en la fase de investigación policial, además de la comprobación de que sólo el $1 \%$ de los crímenes fueron juzgados de un total de 1.896. En cuanto a los demás resultados del estudio, se concluye por la necesidad urgente de elaboración de nuevas metodologías de trabajo para el efecto, dentro de los límites legales, la captura del autor del crimen aún en situación de flagrante delito.

Palabras clave: flujo de la justicia criminal; homicidio doloso; análisis de supervivencia.

\section{EFFICACITÉ DE LA JUSTICE PÉNALE: ÉVALUATION DYNAMIQUE DANS UNE ÉTUDE DE CAS}

L'objet principal de l'article est l'une des principales causes qui contribuent au maintien ou à l'augmentation des crimes de crimes consommés: l'impunité. Ce fait a motivé la conduite d'une analyse dynamique tout au long des processus judiciaires. Les données ont été utilisées pour les cas d'homicides intentionnels survenus en 2014 dans la ville de Fortaleza, et leur vérification temporelle a été suivie afin de vérifier la représentativité de la partie de ces crimes à laquelle aucune sanction n'a été imposée par la loi. Avec l'application des techniques d'analyse de survie aux phases du processus de recherche, se distingue du fait que le plus grand obstacle à l'enquête sur les crimes émergents dans la phase d'enquête de la police, en plus de preuves de seulement $1 \%$ des crimes ont été jugés au total 1896 engagés. En plus des autres résultats de l'étude, il est conclu qu'il est urgent d'élaborer de nouvelles méthodes de travail afin de réaliser, dans les limites légales, la capture de l'auteur du crime encore en situation de flagrant délit.

Mots-clés: criminal justice flow; dolly homicide; analyse de survie.

JEL: K14; K40; K42.

\section{INTRODUÇÃO}

$\mathrm{O}$ combate à criminalidade tem sido um dos objetos de maior atenção na agenda dos formuladores de política no Brasil nos últimos anos. Com efeito, mesmo com um ambiente de elevada instabilidade política e de crise econômica, o aumento da violência de forma generalizada no país compóe o grupo dos maiores desafios aos gestores públicos.

O próprio cenário político que se desenha para as eleiçôes de 2018 tem na política de melhoria da segurança pública uma linha de debate explorada por todos os potenciais candidatos. Nesse debate político, a intolerância da população ao nível 
de insegurança do país estimula inclusive a busca por soluções extremistas como forma de promoção dos candidatos a cargos públicos nos três níveis de governo.

$\mathrm{Na}$ busca por uma solução a este problema, os livros básicos de economia já investigavam esse problema com ferramentas elementares como um simples diagrama de oferta e demanda. No exemplo mais trivial, o gestor público teria duas opçóes para o combate ao comércio de drogas ilegais, quais sejam o aumento do poder de polícia ou o investimento em educação. A partir deste simples exemplo, o que se já se observava é que, enquanto o investimento em educação ataca a atividade ilegal a partir da retração da demanda, desestimulando a prática desses atos pelo menor preço final atribuído ao produto ilícito, o aumento do poder de polícia impacta na retração da oferta do bem nesse mercado, mas o que acaba elevando o preço de equilíbrio e, por conseguinte, estimula a prática da atividade ilícita, no caso do exemplo a venda de drogas náo permitidas por lei.

Os elementos estruturais para o cometimento de açóes criminais são de fato de ordem social, econômica e demográfica, como renda, desigualdade socioeconômica, adensamento populacional e estrutura etária, mas há de se considerar ainda os de cunho coercitivo, como a possível ação do Estado para prevenir e reprimir o crime, por meio do sistema de Justiça criminal.

Em relação aos elementos de ordem social, Cerqueira e Lobão (2004) estimaram a elasticidade da taxa de homicídios em relação a indicadores de renda, desigualdade e gastos com segurança pública e concluíram que o único componente capaz de reverter a trajetória de crescimento na taxa de homicídios foi uma melhora no indicador desigualdade de renda. Andrade e Lisboa (2000), Kume (2004), Araújo Junior e Fajnzylber (2000), Resende e Andrade (2011), entre outros, obtêm resultados semelhantes no tocante à correlação positiva entre desigualdade de renda e taxa de crime. Entretanto, de acordo com Pratt e Godsey (2003), não é necessário haver transformaçóes drásticas no cenário socioeconômico para que se tenha uma redução nas taxas de criminalidade. Isso poderia ser alcançado com a presença de um maior nível de "apoio social", introduzidos por canais públicos ou privados.

No outro extremo de análise, são estudados os efeitos que uma maior repressão causaria de combate à criminalidade. Se, por um lado, como apontado por Cerqueira e Lobão (2004) e Santos (2009), um maior gasto em segurança pública apresenta resultados inócuos ou, no mínimo, ambíguos, por outro, Levitt (2002) estima que cada policial adicional é capaz de reduzir de oito a dez crimes. Em outro estudo, Levitt (1996) ainda obtém estimativas robustas de que um maior nível de encarceramento é capaz de reduzir a taxa de crimes. Além disso, em todos os cenários estudados pelo autor, os benefícios sociais pela redução dos crimes foram iguais ou maiores que os custos do encarceramento adicional. 
O aspecto-chave, portanto, é reconhecer que a crise atual da segurança no Brasil se mostra como um fenômeno de origens complexas e que exige que sejam envidados esforços dos diversos atores e instituições para reversão da tendência explosiva de evoluçấo da criminalidade e sensação de insegurança e, entre as alternativas que extrapolam aquela teoria econômica trivial, emerge o potencial de contribuição do Poder Judiciário nesse processo.

Assim sendo, o que se busca com este estudo é investigar um componente adicional determinante do combate à violência negligenciado na literatura econômica, embora de extrema relevância: a efetividade do Judiciário enquanto inibidor da prática da atividade criminosa. De fato, tanto a impunidade jurídica em si quanto a percepção de impunidade sentida pela sociedade podem ser consideradas como um incentivo para a continuidade das açóes criminosas. Segundo Becker (1968), antes de ingressar em qualquer atividade, seja lícita ou ilícita, o indivíduo analisa os custos e os benefícios, e, sendo estes maiores, procede-se sua prática. No caso das ilícitas, a impunidade reduz um desses custos, referentes ao aprisionamento e à condenação, propiciando, portanto, maior chance para sua prática.

No ordenamento jurídico-penal brasileiro, existe uma gama de delitos que se diferem tanto pelo bem jurídico lesado quanto pela gravidade da lesão ao bem jurídico, ou ainda por sua forma de execução, entre outros aspectos. Os ritos de apuração também são diversos, assim como a pena prevista ou a natureza jurídica do crime, o que influencia diretamente o tempo de julgamento e imposição da pena.

Nesse contexto, qualquer análise da criminalidade de forma agregada implica incorrer em imprecisões pela opção por uma análise superficial. A especial lesividade do homicídio e a sua crescente incidência na sociedade brasileira justificam a sua análise em separado, uma vez que a investigação da eficiência na apuração e no julgamento de sua ocorrência elucide um dos fatores mais importantes para compreensão da importância da variável que representa o fluxo da Justiça criminal enquanto instrumento de combate a esse problema social.

Junto aos outros delitos dolosos contra a vida, o homicídio é o que recebe um tratamento diferenciado no ordenamento jurídico brasileiro, haja vista o próprio rito de apuração (Rito do Tribunal do Júri), definido pelos artigos $406 \mathrm{a}$ 497 do Código de Processo Penal, ${ }^{5}$ com redação dada pela Lei no 11.689/2008. Náo obstante, esse tipo de crime, diferentemente do que ocorre com vários outros (como furtos, roubos, receptação, apropriação indébita, ofensas à honra, violação à propriedade intelectual etc.), é um dos menos sujeitos ao sub-registro, fato que justifica uma análise quantitativa dessa variável. Essa sujeição se dá principalmente em casos de homicídio consumado (morte da vítima), em decorrência da maior

5. Disponível em: <www.planalto.gov.br>. 
dificuldade de desaparecimento dos vestígios materiais da infração, notadamente o corpo de delito (que, no homicídio, consiste no próprio corpo da vítima).

Tendo em vista a particularidade dessa modalidade de crime, busca-se contribuir com subsídios à formação de políticas eficazes no combate à violência generalizada nas cidades brasileiras. Para isso, faz-se uma análise do fluxo do sistema de apuração e julgamento dos crimes de homicídio consumados em um estudo de caso restrito aos casos ocorridos em 2014 em Fortaleza, por sua representatividade como a quinta maior cidade do país em população ${ }^{6}$ e pelo destaque dado à violência na capital cearense em nível nacional e mundial. ${ }^{7}$ Cabe destacar que não se trata de um estudo para um período estático apenas, mas, sim, de uma análise temporal que acompanha o processamento dos delitos desde o marco inicial escolhido (prática do crime) até o último estágio procedimental atingindo após o decurso do período de dois anos, que corresponde ao recorte temporal do trabalho.

A participação das despesas na área de segurança pública no orçamento do Governo do Estado do Ceará em $2014^{8}$ correspondeu a 7,8\% do total do orçamento, montante equivalente à soma das despesas com assistência social, cultura, direitos da cidadania, urbanismo, habitação, saneamento, gestão ambiental e organização agrária. ${ }^{9}$ Essa representatividade orçamentária também se destaca como outro elemento-chave para justificar a busca por outros fatores, negligenciados na literatura, que explique a manutenção da criminalidade nesse estado. Nesse sentido, testar-se-á a ineficiência do sistema judiciário como causa mantenedora relevante da criminalidade.

Para tanto, propóe-se uma divisão do fluxo da Justiça criminal em fases e realiza-se o cálculo dos tempos médios de cada fase, os quais são computados de duas formas: o primeiro ocorre por meio de uma média simples; e o segundo, com uma estimativa derivada de técnicas de análise de sobrevivência, que levam em consideração informaçóes censuradas, ou seja, que não terminaram determinada fase. Serão ainda estimadas as funçóes de sobrevivência para cada fase, utilizando o método de Kaplan-Meier, e calculada a probabilidade de um caso de homicídio "terminar" determinada fase, ou seja, prosseguir para a fase seguinte ao longo do fluxo da justiça. Desse esquema metodológico extrai-se um mapeamento do sistema de Justiça criminal na apuração e no julgamento do crime de homicídio,

6. Dois milhões e seiscentos mil habitantes, de acordo com o Instituto Brasileiro de Geografia e Estatística (IBGE). Disponivel em: <https://bit.ly/38xgulk>.

7. Segundo relatório de 2018 de organização não governamental (ONG) mexicana - Segurança, Justiça e Paz -, Fortaleza situa-se em sétimo e segundo lugares no ranking de violência por homicídio em nível mundial e nacional, respectivamente. Destaca ainda que a taxa de homicídios por 1 mil habitantes passou de 44,98 para 83,48, crescimento de 85\%, quando a Organização Mundial de Saúde estabelece que uma taxa acima de 10,0 já caracteriza violência epidêmica.

8. Dados do Fórum Brasileiro de Segurança Pública - anuário de 2016. Disponível em: <https://bit.ly/2M2ji9H>.

9. Todas essas áreas somadas tiveram uma despesa de R $\$ 1.691 .091 .907,30$ e apenas a despesa de segurança pública foi de R\$1.699.603.997,50. Dados coletados do Sistema de Informações Contábeis e Fiscais do Setor Público Brasileiro (Siconfi) do Tesouro Nacional. Disponível em: <https://bit.ly/3027lxS>. 
explicitando os pontos de entrave ao insucesso ou à morosidade para conclusão da investigaçáo e o julgamento desse tipo de crime. Com isso, permite-se inferir sobre o grau de eficiência tanto do poder de polícia em específico quanto do Poder Judiciário para a redução da criminalidade.

O que se conclui de fato é que a baixa eficácia da solução dos crimes e, portanto, da punibilidade, se dá já na inoperância do sistema policial responsável pela apuração dos crimes, sendo a sensação de impunidade uma decorrência natural de um processo que já inicia errado: a menor taxa de eficiência para apuração adequada dos homicídios se dá na fase policial com o baixíssimo número de prisóes em flagrante. Por conseguinte, os remédios jurídicos consolidam esse sentimento que acaba por estimular as diversas atividades ilícitas que crescem exponencialmente no Brasil.

Além desta introdução, este artigo é dividido em mais três seçōes. A seção 2 explicita o funcionamento da Justiça criminal na investigaçáo e no julgamento dos crimes e traz também um resumo da literatura sobre o tema e uma breve explicação sobre as prisóes cautelares no Brasil. A seção 3 é dedicada à análise de sobrevivência, seguida pela seção 4 que expóe as conclusôes.

\section{FLUXO DO SISTEMA DE JUSTIÇA CRIMINAL}

O sistema de Justiça criminal pode ser conceituado, do ponto de vista estrutural, como o conjunto de órgãos que são acionados quando do cometimento de um crime. São eles: a Polícia Militar, a Polícia Civil, o Ministério Público e o Poder Judiciário, que serão considerados neste estudo por serem os responsáveis para apurar, processar e julgar os delitos tipificados no Código Penal ou nas leis penais extravagantes, segundo as diretrizes do Código de Processo Penal ou de Leis Processuais Penais Especiais (Ribeiro, 2010). ${ }^{10}$ Além desses órgãos, há aqueles de execução penal (secretarias estaduais de Justiça, centros de privação provisória da liberdade, penitenciárias etc. $)^{11} \mathrm{em}$ caso de prisão em flagrante ou de prisão preventiva, ou ainda, quando do cumprimento da pena.

No processo de apuração de cada crime de homicídio doloso como em quase todo delito, nem todos os casos conseguem passar por todas as fases de apuração previstas até o julgamento final. Por isso, é também importante mensurar a quantidade dos delitos que não chegam a perfazer toda a trajetória de apuração, identificando onde ocorrem as maiores perdas, bem como o porquê de elas ocorrerem

10. Apesar de não ter função tipicamente apuratória, Polícia Militar foi incluída nesse rol por razões empíricas: tanto em virtude do relevante trabalho que presta junto ao local de crime como também porque, na maioria dos casos, ela é de fato o primeiro órgão público a ter contato direto com a infração.

11. Vale advertir que a Defensoria Pública e a Ordem dos Advogados do Brasil (OAB) não foram incluídas no conceito proposto, apesar de exercerem funções essenciais à Justiça e de contribuírem enormemente para a legitimidade da prestação jurisdicional. A razão da sua não inclusão se deu porque não são instituiç̧̃es sobre as quais pesa, de forma direta, o dever público de promover a eficiência e a eficácia dos atos de apuração dos delitos. 
(Rifiotis, Ventura e Cardoso, 2010). Essas perdas fazem com que o fluxo possua a estrutura de funil, com muitos casos ocorridos/registrados e cada vez menos casos investigados, denunciados e julgados. Ou seja, há uma filtragem dos casos ao longo do tempo.

A análise científica da impunidade deve englobar também a questão do tempo decorrido entre o crime e o seu desfecho. Em outras palavras, não basta a conclusão do processo apuratório (quando se impõe a sanção penal); é necessário ainda que o julgamento ocorra em um tempo suficientemente curto para que se tenha a percepção de que a justiça foi cumprida. No entanto, a trajetória ou as etapas de apuração não poderão ser aceleradas ou decotadas a ponto de serem suprimidos direitos ou garantias de qualquer das partes envolvidas no conflito.

A seguir, será apresentada uma explanação sobre a trajetória de investigação de um crime de homicídio, seguida por uma revisão da literatura sobre o tema.

\subsection{Trajetória de investigação e julgamento dos crimes}

A maioria dos estudos que analisam o tempo de processamento dos crimes de homicídio leva em consideração apenas a fase policial, a data do oferecimento da denúncia e a data da sentença condenatória. Essa simplificação da análise, desconsiderando o tempo despendido entre cada movimentação processual, gera uma perda de informaçáo sobre os fatos e os atores responsáveis pela famigerada "morosidade processual". À medida que se aprofunda a investigação dos atos de apuração dos delitos, observa-se que algumas subetapas ou subfases assumem especial relevo (e poderiam escapar a um olhar meramente panorâmico).

O tratamento dos delitos englobados no espaço amostral deste estudo (homicídios registrados no município de Fortaleza em 2014) revelou a necessidade de se alçar à categoria de fase autônoma do processo apuratório o tempo gasto pela Justiça para a efetivaçáo da citaçáo dos acusados em processo penal. Deveras, em alguns casos, como nos de réus presos, essa etapa foi realizada com razoável facilidade, mas, em outros, como nas açóes penais contra muitos réus em liberdade, essa etapa nem sequer chegou a ser superada, dado que o insucesso na localizaçáo dos citandos implicou o travamento/suspensão da própria ação penal.

$\mathrm{Na}$ esteira desse raciocínio, buscando-se, tanto quanto possível, suprir eventuais lacunas que distanciariam a análise matemática da realidade prática (praxe forense), este estudo trabalhará com seis fases que perfazem os principais estágios percorridos pelos órgáos que compóem o sistema de Justiça criminal, desde o cometimento do crime de homicídio até o seu julgamento, assim divididas:

- policial - inicia-se a partir do momento do cometimento do crime e encerra-se com a última remessa dos autos ao Poder Judiciário; 
- de denúncia - compreende o período entre a última remessa do inquérito e o recebimento da denúncia pelo Poder Judiciário;

- de citaçáo - tem início com o recebimento da denúncia e termina quando da primeira audiência de instruçãó; ${ }^{12}$

- de instrução - corresponde ao tempo entre a primeira audiência de instrução e a emissão da decisão de pronúncia; ${ }^{13} \mathrm{e}$

- de recurso contra pronúncia e julgamento - tempo entre a decisão de pronúncia e a data da sessão de julgamento de júri. ${ }^{14}$

Será ainda considerado o tempo total entre o cometimento do crime até o seu julgamento, de forma agregada, o qual será denominado com pós-julgamento.

\subsection{Literatura sobre fluxo de Justiça criminal no Brasil}

Tendo em conta a literatura brasileira, pode-se dizer que, a partir da década de 1980, cientistas sociais têm se dedicado mais detidamente sobre o estudo do fluxo do sistema de Justiça criminal e sobre o seu grau de eficiência. O trabalho pioneiro de Coelho (1986) foi baseado em dados oficiais do Serviço de Estatística, Demografia, Moral e Política para o Estado do Rio de Janeiro entre 1942 e 1967, os quais permitiram ao autor concluir que apenas $16 \%$ dos indiciados por crimes de roubo, furto, homicídio e estelionato foram condenados.

Além de analisarem o fluxo de processos de homicídio doloso e dos processos de roubo para a cidade do Rio de Janeiro entre 2000 e 2007, Cano e Duarte (2010) buscaram também explicar os fatores que estariam mais associados para se alcançar a sançáo penal por meio de dois enfoques. No primeiro, utilizaram uma abordagem transversal, com dados de Registro de Ocorrências Policiais e de Sentenças, e concluíram que, em média, apenas $8 \%$ dos homicídios e 3\% dos roubos culminaram em uma sanção penal para, pelo menos, um dos acusados. O segundo enfoque se baseou em uma metodologia longitudinal retrospectiva com dados da Vara de Execuçóes Penais, de onde concluíram que crimes com maior número de réus e vítimas e cometidos com o uso de arma de fogo detêm menor probabilidade de ficarem impunes, embora aumente para crimes cometidos fora do domicílio e contra mulheres.

12. Como um processo pode ter vários réus e cada um pode ser citado em uma data diferente, optou-se por considerar que a fase de citação compreende o tempo entre o recebimento da denúncia e a data da primeira audiência de instrução. Dessa forma, restam englobados, inclusive, os desdobramentos entre as várias formas de citação que podem ser utilizadas, além da citação pessoal, que é a mais comum.

13. Por razões metodológicas, optou-se por não tomar como marco temporal de encerramento da fase de instrução criminal as datas de oferecimento das alegações finais pelas partes, uma vez que estas são extremamente variáveis.

14. Para fins de esclarecimento, cumpre salientar que esta fase compreende o estágio procedimental que se desenvolve após a decisão de pronúncia em todos os processos - tanto naqueles em que houve recurso contra essa decisão quanto naqueles em que não houve a interposição do recurso. 
Cabe realçar a contribuição desse estudo ao proceder a divisão entre os crimes cujas apuraçóes se iniciaram com uma prisão em flagrante ou tão somente com a comunicação da ocorrência à polícia. Da totalidade dos casos de flagrante de crimes de homicídio, 26\% haviam sido julgados em comparação com $6 \%$ daqueles que se iniciaram por registro de ocorrência. Nos casos de crimes de roubo, $68 \%$ das apuraçôes iniciadas por prisão em flagrante haviam chegado a uma sanção penal contra 33\% daqueles que não eram flagrantes.

Ribeiro (2010) utilizou dados longitudinais ortodoxos provenientes da Fundação Sistema Estadual de Análise de Dados (Seade) para os crimes de homicídio no estado de Sáo Paulo, entre 1991 e 1998, e concluiu que quase a totalidade dos boletins de ocorrência havia se transformado em inquérito policial, mas apenas $22 \%$ tornaram-se açóes penais, $14 \%$ chegaram à fase de sentença, e $8 \%$, à condenaçáo. Constatou ainda ser de 2,8 anos o tempo médio entre a data do crime e a sentença. Além disso, foram estimados modelos binários, os quais levaram a autora concluir que as características físicas dos acusados seriam mais importantes para explicar a chance de um processo ser esclarecido e sentenciado com condenaçáo do que as características processuais. Entretanto, há de se ter cautela com esse tipo de conclusão, pois o fato de as equaçóes estimadas no estudo terem apresentado baixo poder de explicação pode indicar que características processuais relevantes tenham sido omitidas, as quais poderiam definir, com maior precisão e objetividade, a chance de um processo chegar à fase de condenaçáo.

Misse e Vargas (2009) compararam o fluxo da Justiça criminal para os crimes contra o patrimônio e de homicídio na cidade do Rio de Janeiro em duas séries históricas: de 1953 a 1957, utilizando uma abordagem longitudinal ortodoxa, e de 1997 a 2001, utilizando uma metodologia transversal. Para poder fazer a comparação entre os dois períodos, os autores calcularam, para o primeiro, as taxas de elucidação policial, esclarecimento e condenação. Na série mais antiga, os homicídios eram, em média, mais elucidados e resultavam em maior número de condenaçóes do que as observadas em crimes de roubo. Eles concluíram que, enquanto as taxas para o crime de homicídio permaneceram praticamente constantes nas duas séries, as de crime contra o patrimônio apresentaram uma queda significativa na série mais recente.

Silva (2010) trouxe um novo enfoque ao categorizar os crimes de homicídio a partir de informaçóes de três características do crime: relação entre vítima e agressor, local do crime (residência, via pública, bar etc.) e motivação atribuída pelo promotor quando do oferecimento da denúncia. As informaçôes foram coletadas a partir de 254 denúncias de homicídios dolosos consumados e tentados ocorridos em Belo Horizonte entre 2003 e 2005. Foram definidas nove categorias: conflitos cotidianos, questóes de drogas, vingança, motivos financeiros, conflitos amorosos, trabalho policial, "bala perdida", homicídio simples e outros. 
Em relação à análise de fluxo, a autora fez, assim como proposto neste estudo, uma nova divisão intraprocessual e dividiu as fases entre a denúncia e a pronúncia, entre a pronúncia e a sessão de júri e entre o júri e a execução da pena. A autora analisou em 2007 e 2009 denúncias oferecidas entre 2003 e 2005 e concluiu que, enquanto em 2007 20\% dos casos não tinham sidos pronunciados e 66,6\% não haviam sidos julgados, em 2009 esses valores se reduziram para 5\% e 40\%, respectivamente. De acordo com a amostra utilizada, o tempo médio decorrido entre a data do fato até o seu julgamento foi de 3,4 anos, e a fase mais demorada dos processos foi entre a denúncia e a pronúncia.

Mais do que uma simples verificação das médias dos tempos processuais, Vargas, Magalhães e Ribeiro (2010) inovaram e utilizaram técnicas de análise de sobrevivência para mensurar, de forma mais apurada, a morosidade processual e a probabilidade de um processo ser sentenciado. Essa técnica também será utilizada neste estudo. As autoras utilizaram a mesma base de dados coletada por Vargas (2000) para os crimes de estupro e calcularam que o tempo médio de processamento desde a data do registro da ocorrência até o julgamento passou de 932 dias (média simples) para 1.263 dias (análise de sobrevivência). Concluíram ainda que $80 \%$ dos casos foram sentenciados após 2 mil dias e que a probabilidade de ser sentenciado em quinhentos dias era de 15\%. Destaca-se também nesse trabalho a divisão feita na análise dos casos de processos com réus presos e de processos com réus soltos, em atendimento ao Código de Processo Penal. A aplicação da técnica de análise de sobrevivência resultou que o tempo médio de processamento para o réu solto (1.716 dias) foi quase três vezes maior do que para o réu preso (623 dias).

Analisando a literatura sobre o tema, percebe-se uma grande diversidade na forma de mensuração do fluxo de Justiça criminal em decorrência, principalmente, da base de dados a qual o pesquisador tem acesso. ${ }^{15}$ Este estudo inova em propor uma divisão mais detalhada do fluxo, em especial na parte intraprocessual, pois, enquanto a maioria faz uso apenas das datas de denúncia e de sentença, este utiliza-se das datas do cometimento do crime, do oferecimento e recebimento denúncia, da primeira e última audiência de instrução, da pronúncia e do julgamento no tribunal do júri para dividir o fluxo em cinco fases. O maior detalhamento resulta na identificação mais precisa de onde ocorrem os principais entraves que levam à morosidade ou à não conclusão de um processo de homicídio doloso. ${ }^{16}$

15. O fluxo pode ser longitudinal, longitudinal retrospectivo ou transversal (Rifiotis, Ventura e Cardoso, 2010). Além disso, podem ou não contemplar algumas variáveis boletins de ocorrência ou informações sobre a pena imposta e o seu cumprimento.

16. Inicialmente, pretendia-se investigar se a demora na investigação seria influenciada pela localidade em que o crime ocorreu ou por características dos envolvidos. Entretanto, mesmo após diversos pedidos à Secretaria de Segurança Pública do Estado do Ceará (SSPDS/CE) utilizando como base a Lei de Acesso a Informação (Lei no 12.527/2011) não foram fornecidos dados georreferenciados ou do número de crime por bairro em 2014 . Em relação às características dos indivíduos, também não há informações disponíveis. 


\section{METODOLOGIA}

Esta seção metodológica contempla, inicialmente, o processo de filtragem utilizado para obtenção da base de dados, apresentando uma análise dos tempos entre as fases da Justiça criminal citadas na subseção 2.1, a qual é feita de forma global e também subdividida em processos com réus presos e soltos. Como resultado disso, faz-se uma síntese das evidências amostrais, em seguida, discute-se a abordagem metodológica para análise temporal das fases da Justiça criminal, destacando-se a função de sobrevivência e sua aplicação em dados judiciais.

\subsection{0 processo de filtragem para obtenção da base de dados}

A construção da base de dados iniciou-se com a coleta, na Secretaria de Segurança Pública e Defesa Social do Ceará (SSPDS/CE),${ }^{17}$ dos nomes de todas as vítimas de Crimes Violentos Letais Intencionais (CVLI) em Fortaleza em 2014, ${ }^{18}$ quando foram registrados 1.989 casos. ${ }^{19}$ Nesse contexto, a partir disso, conduz-se a análise dinâmica.

Como o objetivo deste estudo restringe-se à análise dos crimes de homicídio dolosos, foram excluídos os seguintes casos: latrocínio, lesão corporal seguida de morte, vítimas não identificadas, de outra comarca e os de competência das varas de Infância e Juventude, totalizando 1.906 vítimas e 1.896 casos de homicídio. ${ }^{20}$

A partir dos nomes das vítimas, foram feitas consultas junto ao sítio eletrônico dodo Tribunal de Justiça do Estado do Ceará. ${ }^{21}$

Com base nessa pesquisa, foram extraídas informaçóes sobre as datas de remessa do inquérito ao Judiciário, do oferecimento e recebimento da denúncia, bem como as datas da primeira e da última audiência, da pronúncia e da sessão de júri. Todas as informações foram coletadas entre abril e julho de 2016, ou seja, entre dezesseis e trinta meses (em média, quase dois anos) após o cometimento do crime.

Em cada fase, serão apresentadas as informaçóes referentes ao total de processos, em seguida os casos serão divididos em três categorias: flagrante, aqueles oriundos de prisão em flagrante; preso não flagrante, aqueles em que o acusado/réu foi preso preventivamente em algum momento da investigação ou da ação penal ou ainda que se tenha notícia (dentro do processo) que ele se encontra preso nos autos de outro processo; e solto, aqueles em que o acusado/réu se encontra solto, mesmo que tenha sido expedido mandado de prisão preventiva contra ele (não cumprido).

17. Disponível em: <www.sspds.ce.gov.br>.

18. 0 ano de 2014 é o último que a SSPDS/CE divulga o nome das vítimas de CVLI.

19. Ressalte-se que, como a base de dados foi construída a partir do nome das vítimas que vieram a óbito, ela só engloba os homicídios dolosos consumados.

20. Quando o mesmo fato resultou em mais de uma morte, foi considerada apenas uma vítima, a mais velha. Dessa forma, a base de dados é constituída por casos de homicídio (mesmo processo) e não de vítimas.

21. Disponível em: <www.tjce.jus.br>. 


\subsection{Evidências da amostra}

Após o processo de filtragem aplicado aos 1.896 casos de homicídio dolosos consumados divulgados pelas SSPDS/CE, a amostra final resultou em apenas 1.517 casos ( $80 \%$ do total) que foram remetidos ao Poder Judiciário. Portanto, 20\% dos homicídios que chegaram ao conhecimento da Polícia Civil, após dois anos (em média) do cometimento do crime, ou náo tiveram o inquérito policial instaurado, ou não foram encaminhados, nem mesmo por uma vez, ao Judiciário.

A tabela 1 mostra o total de casos em cada fase e a respectiva quantidade de processos concluídos, bem como subdivididos segundo a ocorrência ou não de prisão (e o tipo) ao longo da investigação e da ação penal. Percebe-se de imediato que a fase policial é a que concentra a maior porcentagem de casos não concluídos $(87,9 \%)$. Isso implica dizer que essa expressiva quantidade de casos não conseguiu reunir elementos suficientes acerca da autoria e materialidade do crime que possibilitassem o oferecimento da denúncia por parte do promotor de justiça. A partir dessas informaçôes, independentemente de como o fluxo se comporte na fase judicial, pode-se afirmar que a maior filtragem de processos, e, consequentemente, a maior causa da impunidade, é a fase de investigação policial. Resultados semelhantes são encontrados por Ribeiro (2010), ao constatar que apenas $22 \%$ dos inquéritos de homicídio foram remetidos, e por Vargas, Magalhães e Ribeiro (2010), ao apurarem que apenas 55\% dos inquéritos de estupro instaurados prosseguiram para as demais fases.

TABELA 1

Total de casos em cada fase judicial

\begin{tabular}{|c|c|c|c|c|c|c|c|}
\hline & $\begin{array}{c}\text { Total de } \\
\text { casos }\end{array}$ & $\begin{array}{c}\text { Concluíram } \\
\text { a fase }\end{array}$ & $\begin{array}{c}\text { Não } \\
\text { concluíram } \\
(\%)\end{array}$ & & $\begin{array}{c}\text { Total de } \\
\text { casos }\end{array}$ & $\begin{array}{c}\text { Concluíram } \\
\text { a fase }\end{array}$ & $\begin{array}{c}\text { Não } \\
\text { concluíram } \\
(\%)\end{array}$ \\
\hline Policial & 1.517 & 183 & 87,9 & Instrução & 102 & 46 & 54,9 \\
\hline Flagrante & 28 & 28 & 0,0 & Flagrante & 23 & 17 & 26,1 \\
\hline Preso não flagrante & 73 & 72 & 1,4 & Preso não flagrante & 53 & 21 & 60,4 \\
\hline Solto & 1.416 & 83 & 94,1 & Solto & 26 & 8 & 69,2 \\
\hline Denúncia & 183 & 164 & 10,4 & $\begin{array}{l}\text { Recursos contra pronúncia e } \\
\text { julgamento }\end{array}$ & 46 & 18 & 60,9 \\
\hline Flagrante & 28 & 27 & 3,6 & Flagrante & 17 & 10 & 41,2 \\
\hline Preso não flagrante & 72 & 72 & 0,0 & Preso não flagrante & 21 & 8 & 61,9 \\
\hline Solto & 83 & 65 & 21,7 & Solto & 8 & 0 & 100,0 \\
\hline Citação & 164 & 102 & 37,8 & Pós-julgamento & 1517 & 18 & 1,2 \\
\hline Flagrante & 27 & 23 & 14,8 & Flagrante & 28 & 10 & 35,7 \\
\hline Preso não flagrante & 72 & 53 & 26,4 & Preso não flagrante & 73 & 8 & 11,0 \\
\hline Solto & 65 & 26 & 60,0 & Solto & 1416 & 0 & 0,0 \\
\hline
\end{tabular}

Fonte: Dados da SSPDS/CE.

Elaboração dos autores.

Ademais, constata-se que, dos 183 inquéritos com investigação concluída, 164 foram denunciados $(89,6 \%)$. Entre os casos que não concluíram a fase, 
dezessete foram arquivados $(9,29 \%)$ e dois receberam decisão de declínio de competência $(1,09 \%)$. Entre os motivos para o arquivamento, nove casos foram por morte do indiciado, três por legítima defesa e cinco por restarem exauridas as possibilidades de investigação sem que chegasse a nenhum indiciamento. Nos dois primeiros casos e nos casos de declínio de competência, não há o que se mencionar sobre impunidade. O primeiro (morte do agente) é resolvido com a declaração de extinção da punibilidade, prevista no art. 107, inciso I, do Código Penal; o segundo (de legítima defesa) representa a situação mais comum entre as hipóteses de exclusão da ilicitude do fato, previstas no art. 23 do Código Penal; e, por derradeiro, no terceiro caso, não há impunidade, pois o fato ainda será apreciado, só que por outro juízo. O filtro da impunidade refere-se, então, apenas aos cinco casos arquivados por falta de indiciamento, que representam $0,26 \%$ do total de crimes, $0,33 \%$ do total de crimes remetidos e $2,73 \%$ dos crimes com investigação concluída. Assim, dentro do período analisado, esse quantitativo não tem efeito relevante para fins de aferiçáo do correspondente filtro de impunidade. Ressalte-se que estudos transversais, que consideram apenas o número de arquivamentos, sem atentar para as suas razóes, obtêm resultados viesados.

$\mathrm{Na}$ fase de citação, dos 164 casos denunciados, a maioria foi finalizada e apenas $37,8 \%$ dos casos permaneceram nessa fase. Da leitura dos processos, percebeu-se que é muito comum só se conseguir efetuar a citação pessoal do réu quando este é preso, seja por força de um mandado de prisão preventiva, seja porque cometeu outro delito posterior e veio a ser preso em flagrante. Outrossim, dos 102 casos que iniciaram a fase de instrução, pouco mais da metade permaneceu nessa fase em 2014.

Muito embora o Código de Processo Penal determine que a audiência de instrução seja una, e, embora não seja raro encontrar processos que atendam esse quesito, forçoso é convir que bem mais comum é encontrar processos que perduram na tentativa de localizar as testemunhas ouvidas na fase policial. É comum também que as testemunhas, ao serem ouvidas em juízo, alterem, total ou parcialmente, o teor de seus depoimentos prestados perante a autoridade do policial Civil, principalmente por medo de represálias dos próprios acusados ou de seus associados. Isso dificulta muito o trabalho acusatório, haja vista que os elementos de convicção produzidos na fase policial precisam ser confirmados em juízo para que possam justificar uma decisão condenatória.

Em relação aos processos que tiveram decisão de pronúncia, do total de 46 apenas 18 foram julgados, ou seja, 61\% dos casos ainda esperam decisão do recurso contra a decisão de pronúncia ou que chegue a data designada para a sessão de julgamento. 
Quando se divide os casos em flagrante, preso não flagrante e solto, percebe-se que em todas as fases os casos com réu solto apresentam maior porcentagem dos que não conseguiram terminar a fase. Merecem destaque as fases policial e de recurso contra a decisão de pronúncia e julgamento. No primeiro, enquanto todos os casos iniciados com prisão em flagrante e $98,6 \%$ dos casos de preso não flagrante tiveram a investigação concluída, no caso de réu solto esse valor foi de apenas 5,9\%. No que tange a fase de julgamento, quase $60 \%$ dos casos oriundos de prisão em flagrante foram julgados, o que não ocorreu com nenhum processo de réu solto.

Analisando o denominado pós-julgamento (ver definição em 2.1), fica evidente a grande impunidade aos autores de crimes de homicídio. Em média, dois anos após o cometimento de 1.517 crimes de homicídio, apenas dezoito foram julgados, o que representa $1,2 \%$ do total. A exceção se encontra nos crimes iniciados com prisão em flagrante, com 35\% dos casos julgados no mesmo período.

Em resumo, dos 1.517 casos de homicídio analisados, houve apenas 28 flagrantes, o que representa ínfimos $1,85 \%$ do total. Esse resultado demonstra a necessidade de elaboração de novas metodologias de trabalho para as açóes policiais.

\subsection{Análise temporal ${ }^{22}$}

Esta subseção descreve a metodologia utilizada para análise temporal em que cada fase citada na subseçấo 2.1 se desenvolve. Devido à peculiaridade de haver muitos crimes de homicídio cometidos e pouco julgados, a estrutura do fluxo de processamento tem o formato de um funil. Em vista disso, a utilização de média simples ou de outras medidas similares que ignoram essa estrutura de dados tendem a subestimar os resultados, dessa forma são inapropriadas para compatibilizar a ocorrência temporal. Portanto, faz-se necessária a utilização de uma técnica que considere todos os casos, tendo alcançado determinada fase ou não, para a computação dos tempos médios. Nesse sentido, a técnica mais apropriada a lidar com esse desenho dos dados é a de análise de sobrevivência, cuja aplicação com ocorrências criminais iniciou-se no Brasil com Vargas, Magalhães e Ribeiro (2010).

O primeiro passo para o cálculo dessa média é a estimação da função de sobrevivência, que atribui a cada tempo uma probabilidade de um caso de homicídio permanecer em determinada fase. As duas subseçôes subsequentes tratam sobre a metodologia geral para o cálculo dessa função e sua utilização para dados judiciais.

22. A metodologia descrita nesta subseção segue Colosimo e Giolo (2006) e Favero e Belfiore (2015). 


\subsubsection{Função de sobrevivência e o estimador Kaplan-Meier²3}

Uma vez que a variável de interesse em análise de sobrevivência é o tempo transcorrido até a ocorrência de determinado evento, essa abordagem apresenta como principal vantagem a de ser robusta à presença de censura, a qual pode ocorrer quando se perde o acompanhamento de uma determinada observação ao longo do estudo ou quando este termina antes que o evento de interesse aconteça. É importante destacar que essa particularidade é que torna o método apropriado, pois, para o cálculo das estatísticas, são utilizados todos os dados, inclusive os censurados.

Sejam $\delta_{i}$ uma função indicadora da ocorrência de falha ou censura ao longo do processo judicial e $t_{i}$ o tempo de falha para as observaçóes $i(i=1,2,3, \ldots)$, cujos dados podem ser representados pelo par $\left(t_{i}, \delta_{i}\right)$ da seguinte forma: $\delta_{i}=1$, se $t_{i}$, se é um tempo de falha ou $\delta_{i}=0$, se $t_{i}$ é um tempo censurado.

A função de sobrevivência, $S(t)$, definida como a probabilidade do evento $T$ não falhar até determinado tempo $t$, é uma forma de representar o tempo de sobrevivência, variável aleatória contínua e não negativa, que pode ser descrita como segue: $S(t)=P(T>t)=1-F(t)$, em que $F(t)$ é a função de probabilidade acumulada.

Pode-se representar o tempo de sobrevivência por meio da função falha ou função risco, $\lambda(t)$, que é a probabilidade de que o evento de interesse ocorra em um determinado intervalo de tempo, $\Delta t$, dado que ele ainda não ocorreu.

$$
\lambda(t)=\frac{s(t)-s(t+\Delta t)}{\Delta t s(t)} .
$$

A função de sobrevivência pode ser estimada utilizando estimador não paramétrico de Kaplan-Meier (1958). Na ausência de censura, ele pode ser definido como a razão entre o número de observaçóes que falharam até o tempo te o número total de observaçóes. Na presença de censura, suponha que as falhas (evento de interesse) ocorram no tempo $t_{j} \operatorname{com} j=1,2, \ldots, k$ e seja $d_{j}$ o número de falhas. Então, considerando $n_{j}$ o número de observaçóes que ainda não sofreram o evento em $t_{j}$, $S(t)$ pode ser escrito em termos de probabilidade condicional da seguinte forma:

$$
\hat{S}(t)=\prod_{j: t_{j}<t}\left(\frac{n_{j}-d_{j}}{n_{j}}\right)=\prod_{j: t_{j}<t}\left(1-\frac{d_{j}}{n_{j}}\right) .
$$

Pode-se ainda dividir as observaçóes em grupos, ou estratos, distintos e comparar as suas curvas de sobrevivência. Neste estudo, assim como feito na seção 3, os casos são divididos em três grupos, de acordo com a presença ou não de prisão (e o tipo): flagrante, preso náo flagrante e solto.

23. Embora se tenha conhecimento que a maioria dos estudos que utilizam essa metodologia associa à análise da função de sobrevivência o modelo de regressão de Cox, optou-se neste estudo por não utilizá-lo, visto que esse modelo serve para avaliar o efeito de covariadas no evento de interesse (nesse caso, o término de cada fase). Uma das principais suposições do modelo é que indivíduos (casos de homicídio) de grupos diferentes apresentam funções da taxa de sobrevivência proporcionais entre si. No presente caso, a única variável citada no estudo que poderia ter influência na variável de interesse é justamente a variável indicativa de grupos, o que prejudicaria a análise. 
Para a comparação das curvas de sobrevivência será utilizado o teste de log-rank (Mantel, 1966). Esse teste analisa os eventos que foram observados em cada grupo e os compara com os seus valores esperados, sob a hipótese nula de que o risco é o mesmo para todos os grupos, ou seja, $H_{0}: \lambda_{1}(t)=\lambda_{2}(t)=\cdots=\lambda_{k}(t)$, com $k$ igual ao número de estratos. A hipótese alternativa é que pelo menos uma função é diferente da outra, ou seja, no caso de três ou mais estratos, que é a realidade deste estudo, rejeitar a hipótese nula não significa dizer que todas as funçōes de sobrevivência diferem significativamente entre si, basta que apenas uma se comporte assim. Ressalte-se ainda que a hipótese é feita para todo o tempo de sobrevivência e que, portanto, pode haver trechos de duas ou mais curvas semelhantes, e, mesmo assim, elas diferirem entre si (Carvalho et al., 2011). Como há três estratos (flagrante, preso não flagrante e solto), adicionalmente, será realizado o teste $\log$-rank (Cox-Mantel) para a comparação das funçóes de sobrevivência em pares.

\subsubsection{Análise de sobrevivência e dados judiciais}

Para utilizar a técnica de análise de sobrevivência, é necessário definir o tempo inicial do estudo, a escala de medida do tempo, o evento de interesse (falha) e o que constitui a censura.

A escala de medida do tempo é em dias e serão calculadas as médias intrafases. Assim, para a primeira fase, o tempo inicial é o cometimento do crime e, para cada fase subsequente, o tempo inicial é o fim da fase anterior. Por sua vez, o evento de interesse será o fim da respectiva fase, da seguinte forma: i) fase policial - remessa dos autos policiais ao Poder Judiciário; ii) fase de denúncia recebimento da denúncia; iii) fase de citação - primeira audiência de instrução; iv) fase de instrução - decisão de pronúncia; e v) fase de recurso contra pronúncia e julgamento - sessão de julgamento do júri. Será ainda calculado o tempo total para o julgamento, cujo tempo inicial é o cometimento do crime e o evento de interesse é a sessão de julgamento do júri.

Por sua vez, as censuras são aqueles processos que ainda não terminaram determinada fase. Foram excluídos dessa análise os processos classificados como não encontrados, pois não pode haver censura no tempo inicial. O espaço amostral do estudo são os 1.517 casos remetidos ao Poder Judiciário e, assim como na sessão anterior, os casos foram divididos segundo a existência ou não de prisões cautelares durante o curso do processo, totalizando três grupos: flagrante, preso não flagrante e solto.

Em síntese, serão estimadas as funçôes de sobrevivência para cada fase e para o período total entre o cometimento do crime e o seu julgamento (denominado pós-julgamento), utilizando o estimador de Kaplan-Meier, e, a partir dessa função, serão estimados os tempos médios de cada uma das fases citadas na subseção 2.1. 


\subsection{Resultados}

\subsubsection{Tempo médio estimado}

As estimativas dos tempos médios que um caso de homicídio leva para terminar determinada fase da investigação ou da ação penal estão dispostas na tabela 2, as quais referem-se a todas as fases propostas, total de casos e dividindo-os segundo a ocorrência (e o tipo) de prisão. Cabe frisar, conforme visto na subseção 3.3, que, quanto maior a quantidade de casos censurados, mais subestimados são os resultados derivados da média simples em relação à técnica de análise de sobrevivência, que, por utilizar em seu cálculo todos os casos, tendo eles concluída a fase ou não, apresenta resultados mais fidedignos.

TABELA 2

Estimativas do tempo médio (dias) de cada fase do fluxo da Justiça criminal

\begin{tabular}{|c|c|c|c|c|c|}
\hline & Média simples & $\begin{array}{c}\text { Análise de } \\
\text { sobrevivência }\end{array}$ & & Média simples & Análise de sobrevivência \\
\hline Policial & 231,99 & 492,06 & Instrução & 169,58 & 399,95 \\
\hline Flagrante & 13,28 & 13,28 & Flagrante & 228,14 & 280,45 \\
\hline Preso não flagrante & 241,71 & 248,92 & Preso não flagrante & 126,94 & 407,77 \\
\hline Solto & 290,96 & 557,13 & Solto & 157,81 & 493,63 \\
\hline Denúncia & 67,26 & 101,49 & $\begin{array}{l}\text { Recursos contra pro- } \\
\text { núncia e julgamento }\end{array}$ & 152,89 & 331,96 \\
\hline Flagrante & 79,33 & 79,44 & Flagrante & 159,4 & - \\
\hline Preso não flagrante & 53,49 & 53,49 & Preso não flagrante & 147 & - \\
\hline Solto & 94,12 & 157,93 & Solto & - & - \\
\hline Citação & 252,99 & 268,47 & Pós-julgamento & 499,28 & 852,5 \\
\hline Flagrante & 169,3 & 208,69 & Flagrante & 479,6 & - \\
\hline Preso não flagrante & 252,98 & 254,38 & Preso não flagrante & 523,88 & - \\
\hline Solto & 318,48 & 338,33 & Solto & - & - \\
\hline
\end{tabular}

Elaboração dos autores.

Focando a análise primeiramente no total de casos em cada fase (sem a subdivisão por tipo de prisão), nota-se que a fase mais demorada é a fase policial. Demora-se, em média, um ano e quatro meses apenas para concluir a investigação de um crime de homicídio e se iniciar a etapa judicial, sendo esta fase uma das grandes responsáveis pela sensaçáo de impunidade.

Quanto à conclusão da fase de denúncia, mostrou-se relativamente rápida. Por sua vez, na fase de citação, observa-se, muitas vezes, uma dificuldade de localização do réu. Em relação à de fase de instruçáo, cabe esclarecer que sua demora se deve, principalmente, à dificuldade de localizar as testemunhas ouvidas na fase policial. Por fim, a lentidão da fase denominada de recurso contra pronúncia e julgamento se dá, muitas vezes, devido à grande quantidade de recursos interpostos e à demora na apreciação desses recursos pelo Tribunal de Justiça. 
O tempo médio estimado entre o cometimento do crime e o seu julgamento pelo Tribunal do Júri (o que no trabalho foi denominado pós-julgamento) foi de 852 dias, ou seja, aproximadamente 2,3 anos. Comparando com outros estudos realizados para o estado de São Paulo, Ribeiro (2010) concluiu que, em média, o julgamento do crime de homicídio demora 2,8 anos, enquanto Adorno e Izumino (2007), com base em estudos de Adorno (1991; 1994) e Izumino (1998), encontraram que referido tempo é, em média, dois anos. Para a cidade de Belo Horizonte, Silva (2010) estimou esse tempo em 3,4 anos.

Analisando os tempos médios estimados intrafases, de acordo com a subdivisão segundo a ocorrência ou não de prisão, percebe-se que os casos de flagrante e preso não flagrante são sempre inferiores aos de réus soltos. A maior diferença é observada justamente na fase policial, em que todos os casos de flagrante tiveram a investigação concluída com tempo médio de treze dias.

\subsubsection{Funções de sobrevivência}

O gráfico 1 mostra a estimativa da função de sobrevivência (probabilidade) da fase policial em relação ao tempo transcorrido (dias), utilizando o estimador de Kaplan-Meier para o total de casos e subdividido segundo a ocorrência (e o tipo) de prisão. Neste estudo, "sobreviver" significa permanecer em determinada fase, ou seja, algo indesejável para a sociedade. Para fins de interpretação do gráfico, quanto mais à esquerda a curva estiver, mais rápido o evento de interesse (fim de cada fase) ocorrerá. 
GRÁFICO 1

Função de sobrevivência: fase policial

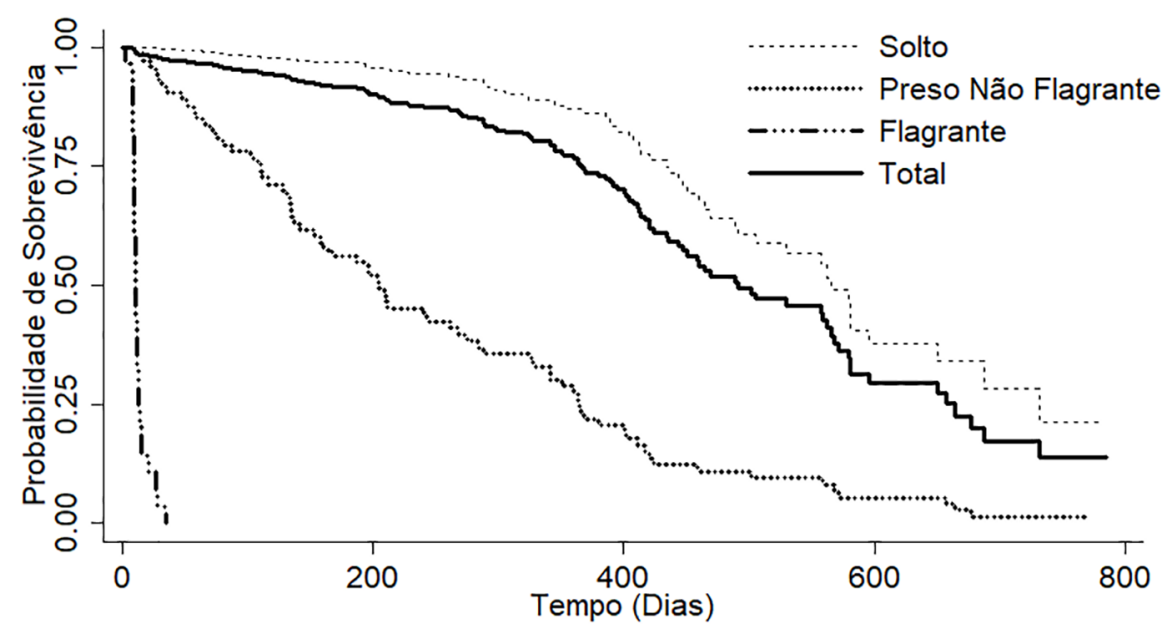

Elaboração dos autores.

Obs.: 1. De acordo com o teste de log-rank, rejeita-se a hipótese nula de igualdade das funções de sobrevivência (apêndice A).

2. Figura cujos leiaute e textos não puderam ser padronizados e revisados em virtude das condições técnicas dos originais (nota do Editorial).

Percebe-se que as funçôes de sobrevivência referentes ao total de casos e de réu solto se comportam de maneira bastante similar, pois, conforme argumentado na subseção 3.2, a expressiva maioria dos casos transcorre sem a imposiçẫo (ou o cumprimento) de alguma prisão cautelar. Extrai-se do gráfico que essas duas funções de sobrevivência são côncavas até aproximadamente 450 dias após o cometimento do crime, quando passa a ser convexa. Assim, até atingir o ponto de inflexáo, a probabilidade de não atingir o evento de interesse (que na fase policial é a conclusão das investigaçóes) se mantém bastante elevada, em torno de $70 \%$ para réu solto e 57\% para o total de casos; 785 dias posterior ao crime, essas probabilidades passam a ser de $21 \%$ e $14 \%$, respectivamente.

Referente aos casos iniciados com prisão em flagrante, por sua vez, a função decresce rapidamente apenas alguns dias após a data de cometimento do crime. Após dez dias, a probabilidade de um caso não ter a investigação concluída é de $61 \%$. Com vinte dias, esse valor já passa a ser de $14 \%$ e com 28 dias a probabilidade tende a $0 \%$. A função de sobrevivência dos casos preso não flagrante, por sua vez, comporta-se de maneira intermediária entre as curvas de flagrante e solto.

A função de sobrevivência da fase denúncia para o total de casos e segundo a divisão proposta é ilustrada no gráfico 2 . Essa função foi estimada utilizando apenas os 183 casos que concluíram a fase policial, de acordo com dados da 
tabela 1. Conforme se pode visualizar no gráfico, a função de sobrevivência para o total de casos decresce de forma bastante acentuada até aproximadamente cem dias após o seu início (conclusão das investigaçóes). Isso indica que essa fase transcorre com relativa rapidez, com muitos casos terminando logo e poucos que ainda perduram muitos dias, mas com baixa probabilidade de sobrevivência (permanecer na fase).

\section{GRÁFICO 2}

Função de sobrevivência: fase de denúncia

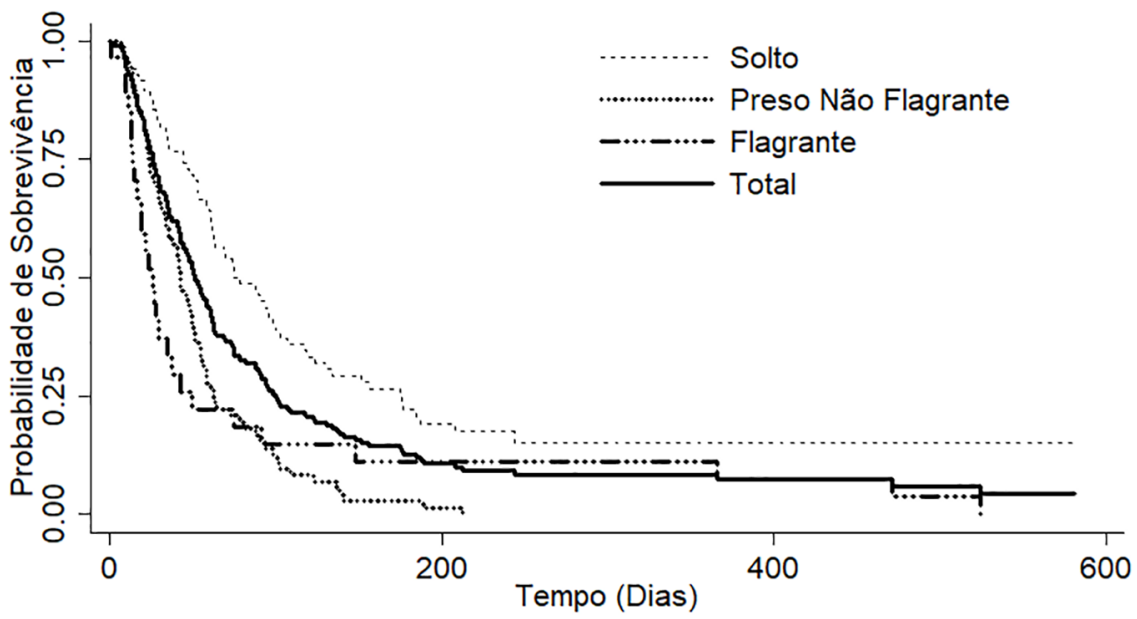

Elaboração dos autores.

Obs.: 1. 0 teste de log-rank (apêndice A) rejeita a hipótese nula de igualdade entre as curvas. Na comparação entre os pares, não se pode rejeitar a hipótese nula de igualdade entre as funções de preso não flagrante e flagrante.

2. Figura cujos leiaute e textos não puderam ser padronizados e revisados em virtude das condições técnicas dos originais (nota do Editorial).

A curva de casos com réu solto, como esperado, está mais à direita durante toda a sua extensão, enquanto as curvas de flagrante e preso não flagrante possuem características semelhantes, pois ambas se iniciam com uma acentuada queda e se estabilizam com baixa probabilidade de sobrevivência. Uma das possíveis explicaçóes para o andamento processual semelhante nesses dois casos é que muitas vezes o pedido de prisão preventiva é feito junto ao oferecimento da denúncia por parte do promotor de justiça e, caso o mandado seja expedido e cumprido com celeridade, os dois casos estariam no mesmo patamar de prioridade. A probabilidade de que a denúncia seja recebida pelo juiz duzentos dias após a conclusão das investigações é de $99 \%$ para os casos de preso não flagrante e de $89 \%$ para os casos de flagrante.

O gráfico 3 mostra o comportamento da função de sobrevivência, estimada via Kaplan-Meier, para os 164 casos que iniciaram a fase de citação, para o total de casos e de acordo com a subdivisão proposta. Esta fase é, em geral, bastante 
morosa, visto que, para o total de casos, a probabilidade de que essa fase termine em noventa dias é de apenas 9\%; em 180, de 33\%; e, em 365 dias, esse valor sobe para $79 \%$. Isso indica que, para a maioria dos casos, a citação é realizada entre seis meses e um ano a partir do recebimento da denúncia.

GRÁFICO 3

Função de sobrevivência: fase de citação

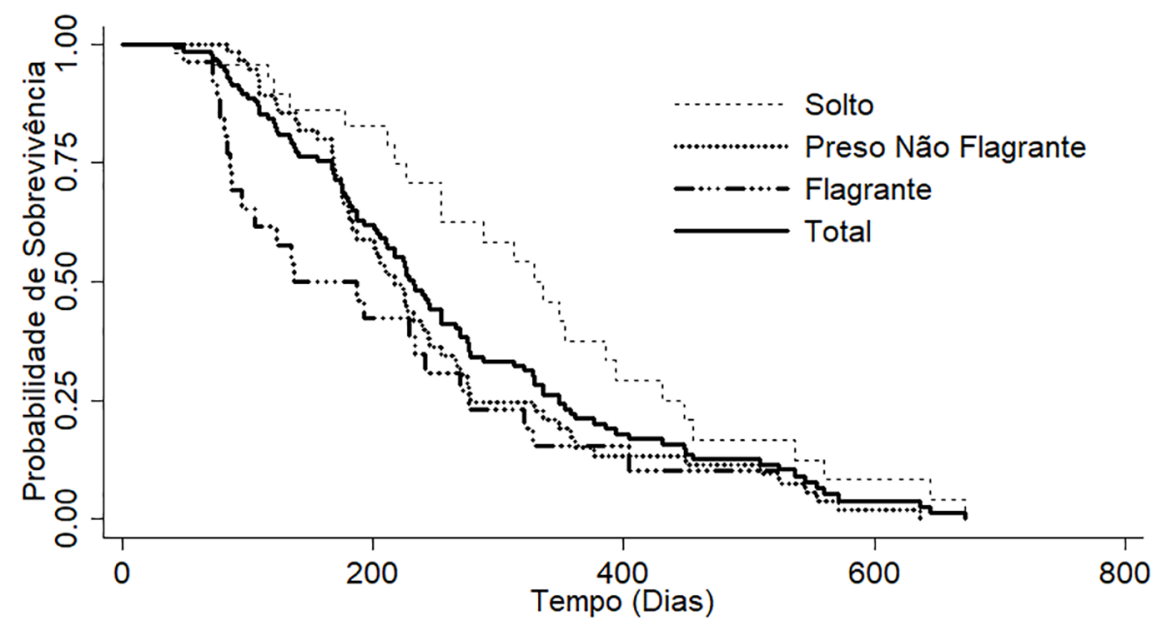

Elaboração dos autores.

Obs.: 1 . 0 teste geral rejeita a hipótese nula de igualdade das funções de sobrevivência, indicando que pelo menos uma difere significativamente das demais. Na comparação aos pares, rejeita-se a hipótese nula de igualdade da função solto com as demais, porém não se rejeita a igualdade entre as funções flagrante e preso não flagrante (apêndice A).

2. Figura cujos leiaute e textos não puderam ser padronizados e revisados em virtude das condições técnicas dos originais (nota do Editorial).

Em relação à subdivisão dos casos em flagrante, preso não flagrante e solto, um ano após o recebimento da denúncia, a probabilidade de que a fase de citação termine, ou seja, que se realize a primeira audiência de instrução é, respectivamente, de $85 \%, 85 \%$ e $62 \%$. As funçóes de sobrevivência nos três casos apresentam comportamento semelhante, com a função solto predominantemente à esquerda e a funçáo flagrante à direita.

O gráfico 4 mostra a função de sobrevivência para o total de casos e segundo a ocorrência (e o tipo) de prisão para os 102 casos que iniciaram a fase de instrução. 
GRÁFICO 4

Função de sobrevivência: fase de instrução

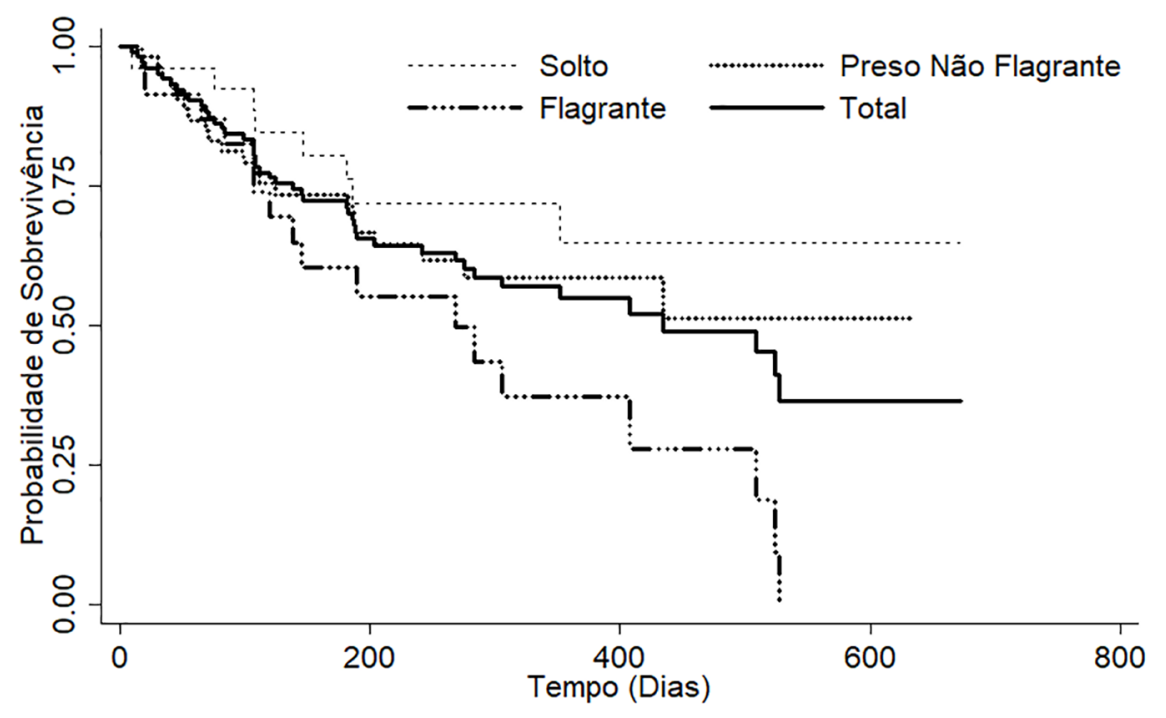

Elaboração dos autores.

Obs.: 1. Dados para o município de Fortaleza em 2014.

2. 0 teste de log-rank rejeita a hipótese nula de igualdade entre as três funções. Na análise aos pares, verifica-se que a função de sobrevivência relativa aos casos de flagrante apresenta-se significativamente diferente das demais e que não se pode rejeitar a hipótese de igualdade entre as funções preso não flagrante e solto (apêndice A).

3. Figura cujos leiaute e textos não puderam ser padronizados e revisados em virtude das condições técnicas dos originais (nota do Editorial).

Para o total de casos, percebe-se na ilustração que, em relação às fases anteriores, a funçáo de sobrevivência se apresenta de forma mais aplainada, o que indica uma maior dispersão. Por exemplo, diferente da fase de denúncia, em que há uma acentuada queda no início da curva, o que indica que uma grande quantidade de processos consegue terminar nos primeiros dias, neste caso, a probabilidade de um processo terminar em duzentos dias não difere acentuadamente da probabilidade de terminar em quatrocentos dias. A título de ilustração, essas probabilidades são, respectivamente, $34 \%$ e $45 \%$.

Em relação à divisão proposta, nota-se que, até aproximadamente duzentos dias, três funçôes apresentam comportamento semelhante. Referente aos casos de flagrante, a função decresce até a probabilidade de a fase de instrução não terminar tender a zero em 527 dias após o seu início. As funçóes preso não flagrante e solto, por sua vez, estabilizam-se com probabilidade de não terminar a fase superior a $50 \%$.

O gráfico 5 mostra as funçóes de sobrevivência, estimada via Kaplan-Meier, para o total dos casos e segundo a subdivisão proposta para os 46 casos que iniciaram a fase de recurso contra pronúncia e julgamento. 
A função de sobrevivência solto é representada por uma linha horizontal, com probabilidade de sobrevivência (processo não terminar) igual a 1 , por não ter nenhum processo julgado (evento de interesse) no período analisado. Por conseguinte, a função de sobrevivência para o total de casos, que nas fases anteriores se apresentava bastante similar à função de solto, nesse caso se aproxima do formato das funçôes flagrante e preso não flagrante.

De forma geral, percebe-se que, até aproximadamente cem dias, as três funçôes possuem comportamento que sugere elevada probabilidade de náo terminar a fase (ser julgado). Por conseguinte, observa-se uma forte queda até aproximadamente duzentos dias, quando volta a se estabilizar. A título de exemplo, as probabilidades de o processo ser julgado em cem e duzentos dias são, respectivamente, de 9\% e 36\%.

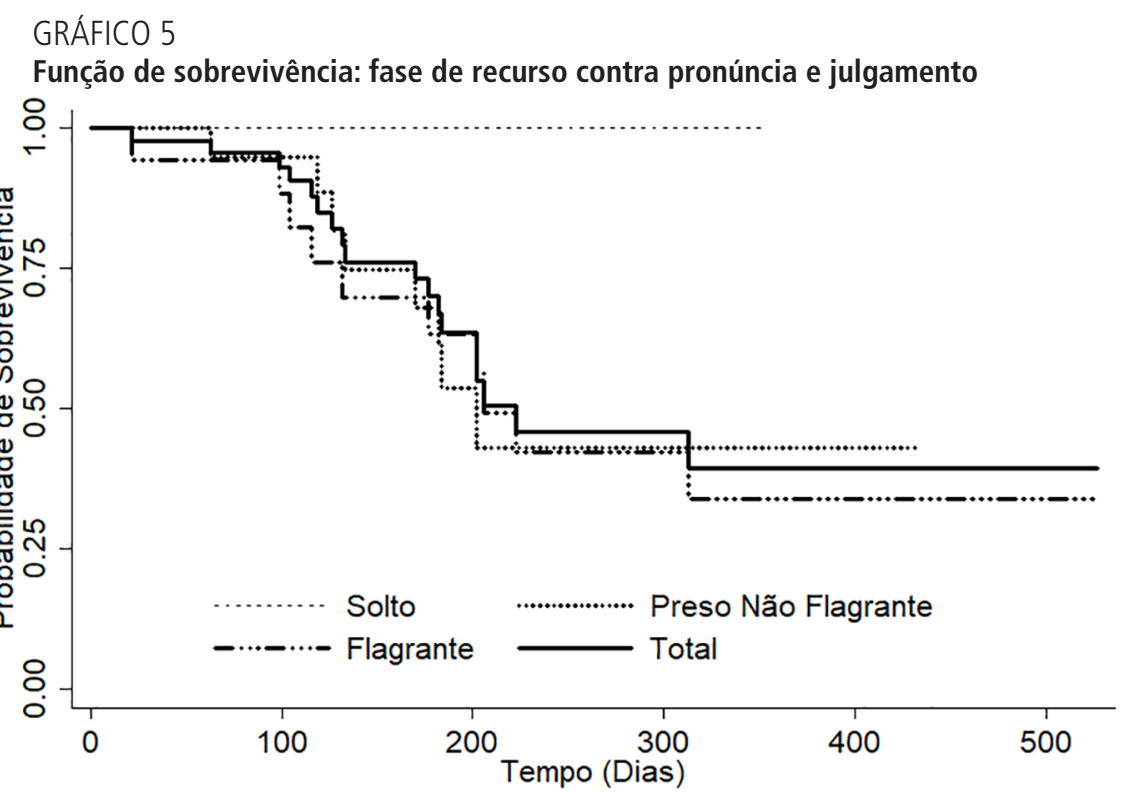

Elaboração dos autores.

Obs.: 1. De acordo com o teste de log-rank, não se pode rejeitar a hipótese de igualdade das funções de sobrevivência. Esse resultado é confirmado pela análise em pares (apêndice A).

2. Figura cujos leiaute e textos não puderam ser padronizados e revisados em virtude das condições técnicas dos originais (nota do Editorial).

Conforme exposto, após a análise intrafase, será realizada uma análise geral, denominada pós-julgamento, cujo tempo inicial é o cometimento do crime e o evento de interesse que é o julgamento do processo. O gráfico 6 mostra a função de sobrevivência para o total de casos e subdivididos segundo a ocorrência ou não de prisão. Como poucos processos alcançaram o evento (foram julgados), a probabilidade de sobrevivência (processo não terminar) se mantém alta durante todo o domínio. 


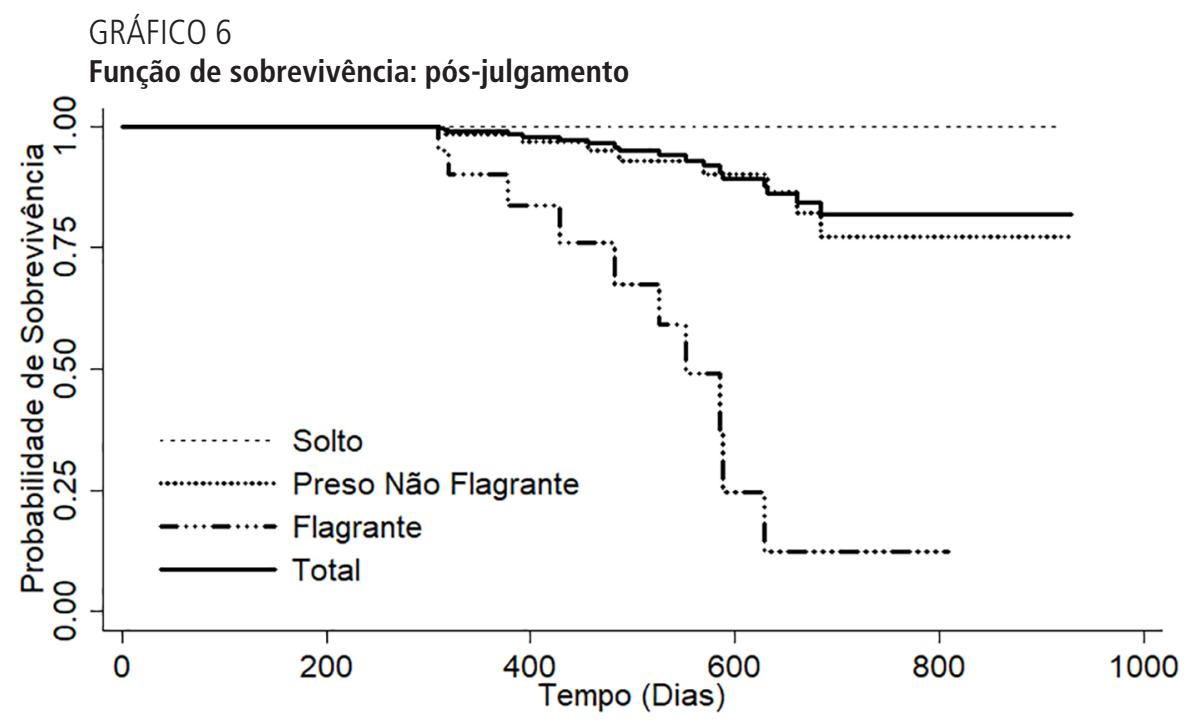

Elaboração dos autores.

Obs.: 1. De acordo com o teste de log-rank, rejeita-se a hipótese nula de igualdade das funções de sobrevivência e, na comparação em pares, todas as funções se mostraram diferentes entre si (apêndice A).

2. Figura cujos leiaute e textos não puderam ser padronizados e revisados em virtude das condições técnicas dos originais (nota do Editorial).

A função referente aos processos com réus soltos se apresenta como uma linha horizontal com probabilidade de sobrevivência igual a 1 por não ter tido nenhum processo julgado. Até aproximadamente trezentos dias, todas as três funçóes apresentam probabilidade de sobrevivência (não terminar) igual a 1. Isso indica que, por mais célere que transcorra a investigação e a ação penal, a chance que se tenha um resultado condenatório até cerca de dez meses após o do crime é quase zero.

Após esse período, a função de sobrevivência flagrante decresce de forma acentuada e se mantém bem mais à esquerda que as demais. Isso indica que os processos que se iniciam com prisão em flagrante são aqueles com maior probabilidade de terminarem e com maior rapidez. Seiscentos e vinte e nove dias após o cometimento do crime, a probabilidade de o processo dessa natureza não ter sido julgado é de apenas $12 \%$.

Por sua vez, as funçóes de sobrevivência para o total de casos e de preso não flagrante passam a decrescer, só que a primeira de forma bem menos expressiva, estabilizando-se com altas probabilidades de não ter o processo julgado. A título de exemplo, novecentos dias após o crime, as probabilidades são, respectivamente, de 82\% e 77\%.

Para sintetizar as informaçóes das funçóes de sobrevivência analisadas, a tabela 3 mostra os valores dos quartis para casa fase, para o total de casos de acordo com a subdivisão proposta e as respectivas probabilidades de um caso concluir a fase em cada um dos quartis. 
TABELA 3

Probabilidade de sobrevivência por quartis da distribuição

\begin{tabular}{lcccccc}
\hline & \multicolumn{3}{c}{ Dias } & \multicolumn{4}{c}{$\begin{array}{c}\text { Probabilidade de passar de fase } \\
\text { (\%) }\end{array}$} \\
\hline \multicolumn{1}{c}{ Fases } & Q1 & Q2 & Q3 & Q1 & Q2 & Q3 \\
\hline Policial & 56 & 109 & 210 & 3,1 & 5,2 & 11,0 \\
Flagrante & 9 & 10 & 13 & 17,9 & 39,3 & 75,0 \\
Preso não flagrante & 111 & 205 & 364 & 26,0 & 50,7 & 75,3 \\
Solto & 57 & 108 & 208 & 0,7 & 1,9 & 4,5 \\
\hline Denúncia & 25 & 50 & 96 & 23,6 & 48,3 & 73,8 \\
$\quad$ Flagrante & 13 & 24 & 43 & 22,1 & 48,1 & 74,0 \\
Preso não flagrante & 24 & 42 & 61 & 25,0 & 48,6 & 73,6 \\
$\quad$ Solto & 36 & 74 & 152 & 23,2 & 47,6 & 72,1 \\
\hline Citação & 71 & 152 & 255 & 2,3 & 23,7 & 58,7 \\
$\quad$ Flagrante & 84 & 137 & 276 & 23,1 & 50,0 & 76,9 \\
$\quad$ Preso não flagrante & 99 & 174 & 254 & 3,5 & 29,5 & 65,7 \\
$\quad$ Solto & 45 & 107 & 244 & 2,0 & 4,5 & 29,1 \\
\hline Instrução & 120 & 228 & 353 & 23,6 & 35,6 & 45,0 \\
$\quad$ Flagrante & 107 & 190 & 321 & 26,1 & 44,7 & 62,7 \\
$\quad$ Preso não flagrante & 112 & 225 & 336 & 24,6 & 35,6 & 41,5 \\
$\quad$ Solto & 147 & 313 & 431 & 19,6 & 28,1 & 35,3 \\
\hline Recursos contra pronúncia e & 107 & 177 & 206 & 9,4 & 30,0 & 49,6 \\
julgamento & 116 & 202 & 313 & 24,0 & 43,7 & 66,2 \\
$\quad$ Flagrante & 112 & 170 & 188 & 5,3 & 32,0 & 46,4 \\
Preso não flagrante & 76 & 108 & 181 & 0,0 & 0,0 & 0,0 \\
$\quad$ Solto & 60 & 123 & 249 & 0,0 & 0,0 & 0,0 \\
\hline Pós-julgamento & 320 & 400 & 540 & 10,0 & 16,4 & 40,9 \\
$\quad$ Flagrante & 419 & 540 & 668 & 3,2 & 7,2 & 17,7 \\
Preso não flagrante & 113 & 217 & 0,0 & 0,0 & 0,0 \\
$\quad$ Solto & 58 & & & & &
\end{tabular}

Elaboração dos autores.

Conforme os resultados dispostos na tabela 3, extrai-se que, para o total dos casos da fase policial, $25 \%$ dos que iniciaram essa fase foram censurados ou passaram para a fase de denúncia em até 56 dias, com probabilidade de 3,1\% de dar prosseguimento nesse período. Similarmente, $75 \%$ dos casos foram censurados ou passaram de fase em até 210 dias, com probabilidade de apenas $11 \%$ de seguir adiante.

De forma geral, à exceção das fases de denúncia e citação, e considerando $75 \%$ dos casos que iniciam cada fase, nenhuma outra prossegue para nova fase com chance acima de $50 \%$.

Quando se subdividem os casos segundo a ocorrência de prisão, em observância ao terceiro quartil, nota-se que as maiores probabilidades são encontradas nos casos iniciados com prisão em flagrante. Nos casos solto, com exceção da fase de denúncia, a maior probabilidade observada foi de apenas 35\%. 
Ressalte-se que o pós-julgamento tem probabilidade zero em todos os quartis, pois pelo menos $75 \%$ de todos os casos foram censurados em até 249 dias, e o processo que foi julgado mais rápido durou 310 dias, ou seja, todos os quartis estão localizados em um trecho em que a função de sobrevivência assume o valor constante igual a 1 .

\section{CONSIDERAÇÕES FINAIS}

Considerando a necessidade de elaboração e implementação de políticas públicas alternativas eficazes no combate à criminalidade nas cidades brasileiras, este estudo considera uma análise que extrapola pressupostos básicos aplicados ao combate à impunidade e o respectivo ganho de credibilidade exercido pela eventual sinergia advinda da atuação do Poder Judiciário no tradicional jogo do dilema do prisioneiro ou às abordagens propostas que se fundamentam apenas no simples aumento do poder de polícia ou no investimento em educação.

Como objeto da investigação para um estudo de caso tem-se a trajetória de apuração dos 1.896 casos de homicídios dolosos, praticados e registrados na cidade de Fortaleza em 2014, na modalidade consumada, com apuraçóes que perduraram até 2016.

Observa-se inicialmente que, ao longo do fluxo da Justiça criminal, o sistema vai perdendo a sua eficácia e, portanto, o sistema vai assumindo, assim, a forma de funil em termos de registros de crimes e efetiva penalidade desde a fase policial até a fase de recurso contra pronúncia e julgamento.

O tempo em que cada uma dessas fases se desenvolveu, nos casos em apreço, também foi abordado e medido, por ser um dos aspectos mais impactantes da percepção social da impunidade. Foram utilizados dois diferentes métodos para o seu cálculo: o de média simples e o de análise de sobrevivência, este último incorporando em seu cálculo informaçóes referentes àqueles casos que ainda não conseguiram concluir determinada fase (informação censurada).

A diferença entre os dois métodos em alguns casos foi bastante significativa. $\mathrm{Na}$ fase policial, por exemplo, considerando apenas os 183 casos que tiveram a investigação concluída, o tempo médio de conclusão por meio de um cálculo simples foi de 232 dias, contra 492 dias quando, no cálculo da média, foram consideradas as informaçóes censuradas (análise de sobrevivência). Essa disparidade entre os valores das médias obtidas utilizando duas diferentes metodologias repete-se na maioria das fases, indicando os valores subestimados ao se utilizar a média simples.

Outro aspecto que merece destaque é o tempo médio entre o cometimento do crime e o seu julgamento: apenas dezoito casos foram julgados até julho de 2016. Utilizando média simples, constatou-se que o tempo médio entre o crime e o julgamento foi de 16,6 meses, o que é considerado baixo na literatura. Quando 
se incorporam ao cálculo da média informaçōes sobre os tempos dos processos que ainda não foram julgados, o tempo médio para o julgamento passa a ser de 28,4 meses, valor bem mais próximo daqueles obtidos em outros estados.

A estimação da função de sobrevivência seguindo o método de Kaplan-Meier permitiu ainda o cálculo da probabilidade de um processo terminar determinada fase em um determinado tempo. Nesse aspecto, cabe destacar: i) a probabilidade de que um processo tenha a sua investigação concluída (fase policial) um ano após o crime é de $23 \%$, passando para $54 \%$ após 1,5 ano; ii) a probabilidade de um processo terminar a fase de denúncia em sessenta dias é de $57 \%$, mas em noventa dias aumenta para $70 \%$, indicando a rapidez dessa fase; iii) a fase de citação é, em geral, morosa, quando é de apenas $8,7 \%$ a chance de que essa fase termine em noventa dias, de 33\% em 180 dias e de $79 \%$ em 365 dias a partir do recebimento da denúncia; iv) há uma grande dispersão nos tempos da fase de instrução; e v) uma vez pronunciado, as chances de um processo ser julgado (fase de recurso contra pronúncia e julgamento) em cem e duzentos dias são, respectivamente, de $9 \%$ e $45 \%$.

As evidências deste estudo corroboram ainda o argumento de que a efetividade da atividade policial, como a elevação dos autos de prisão em flagrante, mostra-se como determinante não apenas para celeridade na duração do processo, mas aumenta a chance de condenação e, portanto, reduz a impunidade. O oposto também é verdadeiro, isto é, não sendo caso de flagrante, uma série de implicaçôes negativas sobrevém ao fluxo do sistema de Justiça criminal.

Os resultados evidenciam então a necessidade de elaboraçáo de novas metodologias de trabalho às açôes policiais, enquanto, no tocante ao Poder Judiciário, percebe-se que a aplicação de mecanismos de avaliação da performance pode promover importantes mudanças no cenário da impunidade, na medida em que agilizaria o andamento dos processos. Além dessas medidas, urge que seja criada uma base de dados em nível oficial interligando todos os órgãos que compóem o sistema de Justiça criminal, com dados de ocorrências policiais, inquéritos, denúncias, sentenças, e execuções penais, organizados longitudinalmente, a fim de transmitir transparência, sem obstruçóes ao seu acesso.

\section{REFERÊNCIAS}

ADORNO, S. Violência urbana, justiça criminal e organização social do crime. Revista Crítica de Ciências Sociais, Coimbra, v. 33, p. 145-156, 1991.

. Cidadania e administração da Justiça criminal. In: DINIZ, E. et al. (Orgs.). O Brasil no rastro da crise. São Paulo; Brasília: HUCITEC; ANPOCS; Ipea, 1994. p. 304-327. 
ADORNO, S.; IZUMINO, W. P. A Justiça no tempo, o tempo da justiça. Tempo Social, São Paulo, v. 19, n. 2, nov. 2007.

ANDRADE, M. V.; LISBOA, M. Desesperança de vida: homicídio em Minas Gerais, Rio de janeiro e Sáo Paulo: 1981 a 1997. Rio de Janeiro: FGV, 2000.

ARAÚJO JUNIOR. A. F.; FAJNZYLBER, P. Crime e economia: um estudo das microrregiốes mineiras. Revista Econômica do Nordeste, Fortaleza, v. 31, 2000.

BECKER, G. S. Crime and punishment: an economic approach. Journal of Political Economy, v. 76, n. 2, p. 169-217, 1968.

CANO, I.; DUARTE, T. L., A mensuração da impunidade no sistema de Justiça criminal do Rio de Janeiro. Segurança Justiça e Cidadania, n. 4, Senasp, Ministério da Justiça, 2010.

CARVALHO, M. S. et al. Análise de sobrevivência: teoria e aplicaçóes em saúde. 2. ed. Rio de Janeiro: Editora Fiocruz, 2011.

CERQUEIRA, D.; LOBÃO, W. Criminalidade, ambiente socioeconômico e polícia: desafios para os governos. Revista de Administraçáo Pública, Rio de Janeiro, v. 38, n. 3, p. 371-99, maio/jun. 2004.

COELHO, E. C. A administração da Justiça criminal no Rio de Janeiro: 19421967. Revista de Ciências Sociais, Rio de Janeiro, v. 29, n. 1, 1986.

COLOSIMO, E. A.; GIOLO, S. R. Análise de sobrevivência aplicada. São Paulo: Blucher, 2006.

FAVERO, L. P.; BELFIORE, P. Métodos quantitativos com stata: procedimentos, rotinas e análise de resultados. Elsevier Brasil, 2015.

IZUMINO, W. P. Justiça e violência contra a mulher: o papel do Judiciário na solução dos conflitos de gênero. São Paulo: Annablume/Fapesp, 1998.

KAPLAN, E. L.; MEIER, P. Nonparametric estimation from incomplete observations. Journal of the American Statistical Association, v. 53, p. 457-81, 1958.

KUME, L. Uma estimativa dos determinantes da taxa de criminalidade brasileira: uma aplicação em painel dinâmico. In: ENCONTRO NACIONAL DE ECONOMIA, 32., João Pessoa. Anais... João Pessoa: Anpec, 2004.

LEVITT, S. D. The effect of prison population size on crime rates: evidence from prison overcrowding litigation. Quarterly Journal of Economics, v. 111, n. 2, p. 319-351, 1996.

. Using electoral cycles in police hiring to estimate the effect of police on crime: reply. American Economic Review, v. 92, n. 4, p. 1244-1250, 2002. 
MANTEL, N. Evaluation of survival data and two new rank order statstistics arising in its consideration. Cancer Chemotherapy Reports, v. 50, p. 163-170, 1966.

MISSE, M.; VARGAS, J. D. A produção decisória do sistema de Justiça criminal no Rio de Janeiro ontem e hoje: um estudo preliminar. Revista Brasileira de Ciências Criminais, n. 77, p. 237-260, 2009.

PRATT, T. S.; GODSEY, T. W. Social support, inequality, and homicide: a cross-national test of an integrated theoretical model. Criminology, v. 41, n. 3, 2003. RESENDE, J. P.; ANDRADE, M. A. Crime social, castigo social: desigualdade de renda e taxas de criminalidade nos grandes municípios brasileiros. Revista Estudos Econômicos, São Paulo, v. 41, n.1, jan./mar., 2011.

RIBEIRO, L. A Produção decisória do sistema de Justiça criminal para o crime de homicídio: análise dos dados do estado de São Paulo entre 1991 e 1998. Revista de Ciências Sociais, Rio de Janeiro, v. 53, n. 1, p.159-193, 2010.

RIFIOTIS, T.; VENTURA, A. B.; CARDOSO, G. R. Reflexóes críticas sobre a metodologia do estudo do fluxo de Justiça criminal em caso de homicídios dolosos. Revista de Antropologia, v. 53, n. 2, p. 689-714, 2010.

SANTOS, M. Dinâmica temporal da criminalidade: mais evidências sobre o "efeito inércia" nas taxas de crimes letais nos estados brasileiros. Economia, v. 10, n. 1, p. 169-194, 2009.

SILVA, K. A. O papel dos tipos de homicídio dolosos na construção social da incriminação dos sujeitos pelos promotores de justiça: Belo Horizonte, processos com andamento entre 2007 e 2009. Dilemas: Revista de Estudos de Conflitos e Controle Social, v. 3, n. 8, p. 101-123, 2010.

VARGAS, J. D. Crimes sexuais e sistema de justiça. São Paulo: IBCCRIM, 2000. VARGAS, J. D.; MAGALHÃES, I. B.; RIBEIRO, L. M. L. Tempo da justiça: metodologia de tratamento do tempo e da morosidade processual na Justiça criminal. Brasília: Secretaria Nacional de Segurança Pública, Ministério da Justiça, p. 45-72, 2010. 


\section{APÊNDICE A}

TABELA A. 1

Teste log-rank de igualdade de funções de sobrevivência por fases

\begin{tabular}{|c|c|c|c|c|c|}
\hline \multicolumn{2}{|c|}{ Policial } & \multicolumn{2}{|c|}{ Denúncia } & \multicolumn{2}{|c|}{ Citação } \\
\hline$\lambda^{2}=$ & 2622,92 & $\lambda^{2}=$ & 29,01 & $\lambda^{2}=$ & 8,45 \\
\hline Prob $>\lambda^{2}=$ & 0,00 & Prob $>\lambda^{2}=$ & 0,00 & Prob $>\lambda^{2}=$ & 0,02 \\
\hline \multicolumn{2}{|c|}{ Instrução } & \multicolumn{2}{|c|}{ Recursos contra pronúncia e julgamento } & \multicolumn{2}{|c|}{ Pós-julgamento } \\
\hline$\lambda^{2}=$ & 7,97 & $\lambda^{2}=$ & 2,55 & $\lambda^{2}=$ & 87,85 \\
\hline Prob $>\lambda^{2}=$ & 0,02 & Prob $>\lambda^{2}=$ & 0,28 & $\operatorname{Prob}>\lambda^{2}=$ & 0,00 \\
\hline
\end{tabular}

Elaboração dos autores.

TABELA A. 2

Teste log-rank (Cox-Mantel) de igualdade de funções de sobrevivência por fases

\begin{tabular}{|c|c|c|c|c|c|c|c|c|c|}
\hline \multirow[b]{4}{*}{ Preso não flagrante } & \multicolumn{4}{|c|}{ Policial } & \multicolumn{5}{|c|}{ Instrução } \\
\hline & $\lambda^{2}$ & Prob $>\lambda^{2}$ & $\lambda^{2}$ & Prob $>\lambda^{2}$ & & $\lambda^{2}$ & Prob $>\lambda^{2}$ & $\lambda^{2}$ & Prob $>\lambda^{2}$ \\
\hline & \multicolumn{2}{|c|}{ Solto } & \multicolumn{2}{|c|}{ Preso não flagrante } & \multicolumn{3}{|c|}{ Solto } & \multicolumn{2}{|c|}{$\begin{array}{l}\text { Preso não } \\
\text { flagrante }\end{array}$} \\
\hline & 189,98 & 0,00 & & & $\begin{array}{l}\text { Preso não } \\
\text { flagrante }\end{array}$ & 0,91 & 0,34 & & \\
\hline Flagrante & 2123,41 & 0,00 & 131,13 & 0,00 & Flagrante & 7,82 & 0,01 & 3,94 & 0,047 \\
\hline \multicolumn{5}{|l|}{ Denúncia } & \multicolumn{5}{|c|}{ Recurso contra pronúncia e julgamento } \\
\hline & $\lambda^{2}$ & Prob $>\lambda^{2}$ & $\lambda^{2}$ & Prob $>\lambda^{2}$ & & $\lambda^{2}$ & Prob $>\lambda^{2}$ & $\lambda^{2}$ & Prob $>\lambda^{2}$ \\
\hline & \multicolumn{2}{|c|}{ Solto } & \multicolumn{2}{|c|}{ Preso não flagrante } & & \multicolumn{2}{|c|}{ Solto } & \multicolumn{2}{|c|}{$\begin{array}{l}\text { Preso não } \\
\text { flagrante }\end{array}$} \\
\hline Preso não flagrante & 27,48 & 0,00 & & & $\begin{array}{l}\text { Preso não } \\
\text { flagrante }\end{array}$ & 2,20 & 0,14 & & \\
\hline Flagrante & 13,32 & 0,00 & 0,017 & 0,90 & Flagrante & 2,66 & 0,103 & 0,01 & 0,94 \\
\hline \multicolumn{5}{|l|}{ Citação } & \multicolumn{5}{|c|}{ Pós-julgamento } \\
\hline & $\lambda^{2}$ & Prob $>\lambda^{2}$ & $\lambda^{2}$ & Prob $>\lambda^{2}$ & & $\lambda^{2}$ & Prob $>\lambda^{2}$ & $\lambda^{2}$ & Prob $>\lambda^{2}$ \\
\hline & \multicolumn{2}{|c|}{ Solto } & \multicolumn{2}{|c|}{ Preso não flagrante } & & \multicolumn{2}{|c|}{ Solto } & \multicolumn{2}{|c|}{$\begin{array}{l}\text { Preso não } \\
\text { flagrante }\end{array}$} \\
\hline Preso não flagrante & 5,78 & 0,02 & & & $\begin{array}{l}\text { Preso não } \\
\text { flagrante }\end{array}$ & 12,29 & 0,00 & & \\
\hline Flagrante & 7,00 & 0,01 & 0,93 & 0,33 & Flagrante & 91,13 & 0,00 & 25,77 & 0,00 \\
\hline
\end{tabular}

Elaboração dos autores.

Data da submissão: 28/6/2018

Primeira decisão editorial em: 22/2/2019

Última versão recebida em: 3/5/2019

Aprovação final em: 13/5/2019 